\title{
CATIONIC LIPID NANOEMULSION AS A DRUG DELIVERY SYSTEM IN CANCER AND VIRAL IMMUNOTHERAPY \\ BY
}

\author{
HOSSAM HEFESHA
}

FROM

Department of Pharmaceutics and industrial pharmacy, Faculty of Pharmacy, Al-Azhar University, Cairo, Egypt

\begin{abstract}
The activation of Toll-like receptors (TLR) by natural or synthetic ligands results in cytokine secretion and increased phagocytosis by macrophages and cytolytic activity by natural killer (NK) cells. So,wedeveloped a stable, efficient, and nontoxic cationic nanoemulsion (CNE) suitable for TLR ligand oligonucleotide (ssRNA) delivery. The nanoemulsion is based on squalene, cationic lipid 1,2-dioleoyl-sn-glycero-3trimethylammoniumpropane (DOTAP), helper lipid 1,2-dioleoyl-sn-glycero-3phosphoethanolamine (DOPE), tween 80, and poloxamer 188. Factorial design was used to investigate the influence of of tween 80 and poloxamer 188 on particle size, single strand RNA (ssRNA) binding \%, Interferon (INF $\alpha$ induction). Results showed that by increasing the poloxamer 188 and/or tween 80 , the particle size decreased. The influence of tween 80 and poloxamer 188 concentrations on the particle surface on ssRNA binding efficiency is evident. Although most of the formulations showed a high binding efficiency of ssRNA, only two formulations produced high amount of INF $\alpha$. Interestingly that in both formulations either poloxamer 188 is present $(\mathrm{F} 3)$ or tween 80 is present $(\mathrm{F} 4)$ but where both together in one formulation, the INF $\alpha$ production decreased relatively. In conclusion, cationic nanoemulsion could be a promising drug delivery system for nucleic acids (DNA/RNA) in cancer and viral immunotherapy.
\end{abstract}

\section{Introduction}

Recent molecular biological studies have clarified the function of Toll-like receptors (TLRs) in microbial infection. TLRs are evolutionally conserved transmembrane proteins and play crucial roles as pattern recognition receptors (PRRs). So far, ten and 12 functional TLRs have been identified in humans and mice, respectively (Kawai and Akira, 2010).TLR-1,-2, -4, -5 and -6 are located on the cell surfaces, while TLR-3, $-7 / 8$ and -9 , as depicted in Fig. 1, are 
located in the endosomal compartments with their ligand-binding domains facing the lumen of the vesicle (Akira et al., 2006). The ligands of TLRs have been identified as microbial components from fungi, bacteria or viruses. For example, the natural ligands for TLR-2 are peptidoglycans from Gram-positive bacteria where the heterodimer TLR-1/2 recognizes triacylated lipopeptides and TLR-2/6 recognizes diacylated lipopeptides; TLR-3 recognizes double strand RNA (dsRNA); TLR-4 recognizes lipopolysaccharide in the outer membrane of Gram-negative bacteria; TLR-5 recognizes flagellin of motile bacteria; the natural ligands for TLR-7/8 are guanosine and uridinerich single strand RNA (ssRNA) (Lund et al., 2004; Diebold et al., 2004; Heil et al., 2004); TLR-9 recognizes unmethylated juxtaposed cytosine and guanine nucleotides (CpG) of bacterial DNA (Hemmi et al., 2000; Krieg et al., 2008). For synthetic ligands, imidazoquinoline derivatives, like imiquimod and resiquimod, can activate TLR-7 and TLR-7/8, respectively, have been extensively evaluated in preclinical and clinical studies for their antiviral and anti-cancer effects (Ito et al., 2002; Smits et al., 2008; Hemmi et al., 2002; Schon et al., 2008). TLRs are expressed on different immune subsets, especially monocytes, dendritic cells (DCs) and macrophages. The activation of TLR by natural or synthetic ligands results in cytokine secretion like interferon alpha (IFN- $\alpha$ ), tumor necrosis factor alpha (TNF- $\alpha$ ) and interlukin 12 (IL-12) and increased phagocytosis by macrophages and cytolytic activity by natural killer (NK) cells. The proinflammatory properties of TLR ligands have made them useful as vaccine adjuvants and antiviral and antitumor therapeutics. TLR agonists have shown great promise in preclinical studies, and some of them are entering human trials. With the emergence of clinical trials using TLR agonists, it is becoming evident that TLR natural ligands could be used for cancer and viral immunotherapy. However, the main limitation of this approach is the week stability of the RNAs upon injection in blood. Therefore, it is clear that delivery systems will be required to enhance the potency of the RNA. This drawback for RNA therapy creates a necessity to have a drug delivery system which can protect the RNA from degradation and keep it functional to reach the target organ or cell. So, many formulations have been used for such purpose like cationic liposomes (lipoplexs), cationic polymers (polyplexs), and cationic nanoemulsions (CNE). Despite long standing trials of various co-lipids, only limited number of reports has appeared in the literature concerning successful in vivo applications using cationic liposomes as a gene carrier (Hong et al., 1997; Zelphatiet al., 1998). Cationic liposomes showed aggregation upon mixing with DNA in presence of serum and the optimal transfection activity could be obtained without serum. These large aggregates in serum might be the 
reason for little transfection activity in vivo and lead to embolism as well. Polyplexes showed also high toxicity in vitro and in vivo which might be a reason for abortion of most clinical studies. Cationic emulsions have previously been described as delivery systems for oligonucleotides (Teixeira et al., 1999; Teixeiraet al., 2001) and DNA (Yiet al., 2000). The cationic emulsion has the advantages of ease of manufacture, enhanced stability, safety and low cost in comparison to other Oligonucleotide delivery technologies, including liposomes, gene gun, electroporation and sonoporation. So, we developed cationic lipid nanoemulsions which are physically stable and can facilitate the transfection in vitro and potentially in vivo. This article aims to develop a stable, efficient, and nontoxic cationic nanoemulsion suitable forTLR ligand oligonucleotide (ssRNA) delivery (Fig. 2).The nanoemulsion approach is based on squalene which has been manufactured at large scale and has been used in a commercially approved product as an oil phase. In addition, squalene has been shown to be safe and well tolerated in a number of clinical trials (Brioneset al., 2001). To promote the interaction of RNA with the emulsion, a cationic lipid, 1,2-dioleoyl-3-tri methylammoniumpropane (DOTAP) was used as a surfactant in the formulation. The choice of DOTAP is based on its ability to complex plasmid DNA and its previous use in humans for gene therapy (Thierry et al., 1997; Zabner 1997). Cationic lipid formulations usually require a helper lipid to enhance its transfection activity. One of the most widely used helper lipids is1,2-dioleoyl$s n$-glycero-3-phosoethanolamine (DOPE), especially for in vitro application. The role of the helper lipid is to fuse with the endosomal membrane consequently helps the phagocytosed nucleotide to be released. Among many non-ionic surfactants, the inclusionof Tween 80 and the Brij series which have PEG moieties increased the stability of DOTAP emulsions. They helped to maintain structure and transfection activities during the process of complex formation with DNA under high salt conditions such as PBS (Tae et al., 2002). However, the optimum concentration of tween 80 in the formulation plays a major role in the activity. It was reported also that using of poloxamer 188 enhance the cellular uptake and reduce the efflux of the drug from the cells (Brriger eta al., 2002). So, the aim of this paper is to describe the preparation, characterization and in vitro evaluation of a cationic emulsion with adsorbed ssRNA oligonucleotide. Factorial design was used to investigate the influence of of tween 80 and poloxamer 188 on particle size, ssRNA binding \%, INF $\alpha$ induction. 


\section{EXPERIMENTAL}

\section{MATERIALS}

1,2-dioleoyl-3-trimethylammonium-propane (DOTAP) and 1-palmitoyl-2-oleoyl-snglycero-3-phosphoethanolamine (POPE) were purchased from Avanti Polar Lipids (Alabaster, AL). Tween80, poloxamer 188, and squalene were purchased from Sigma aldrich (St. Louis, MO). ssRNA and ODN2216 were purchased from invivoGen (San Diego, CA 92121 - USA). RNAses free Phosphate buffer saline was purchased from Ambion (Darmstadt, Germany). RNAses free water was purchased from B-Braun (Melsungen, Germany). All of reagents were of analytical grade.

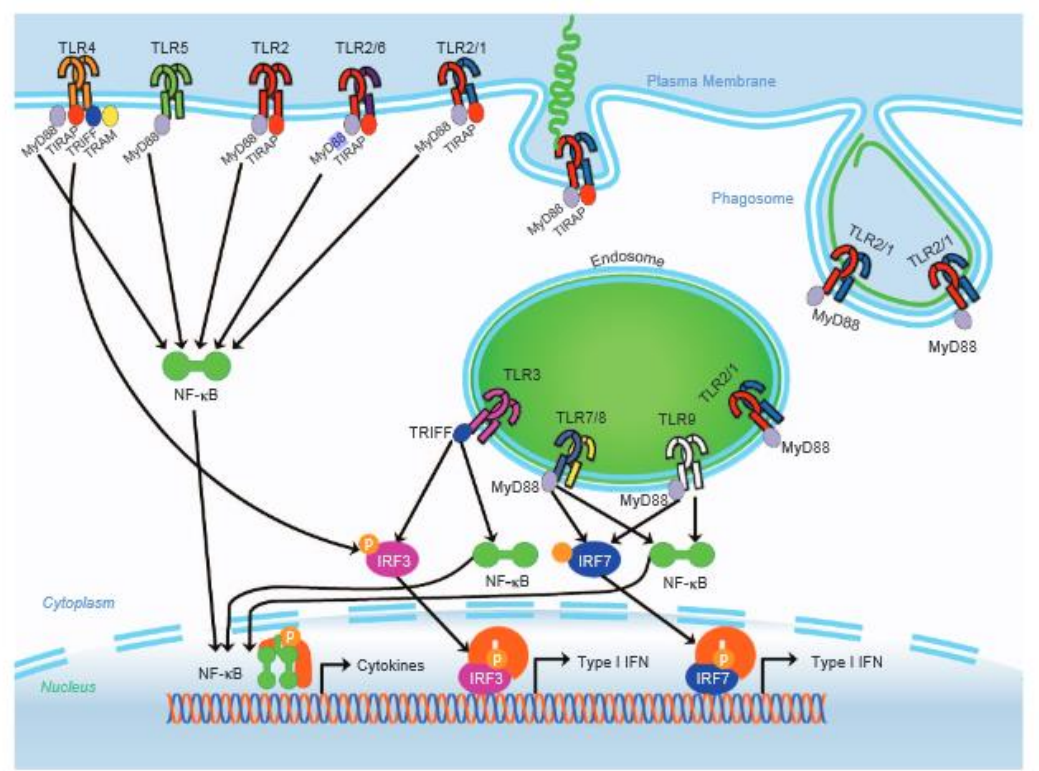

Fig.1. Toll like receptors signalling overview (Jorge et al., 2012).
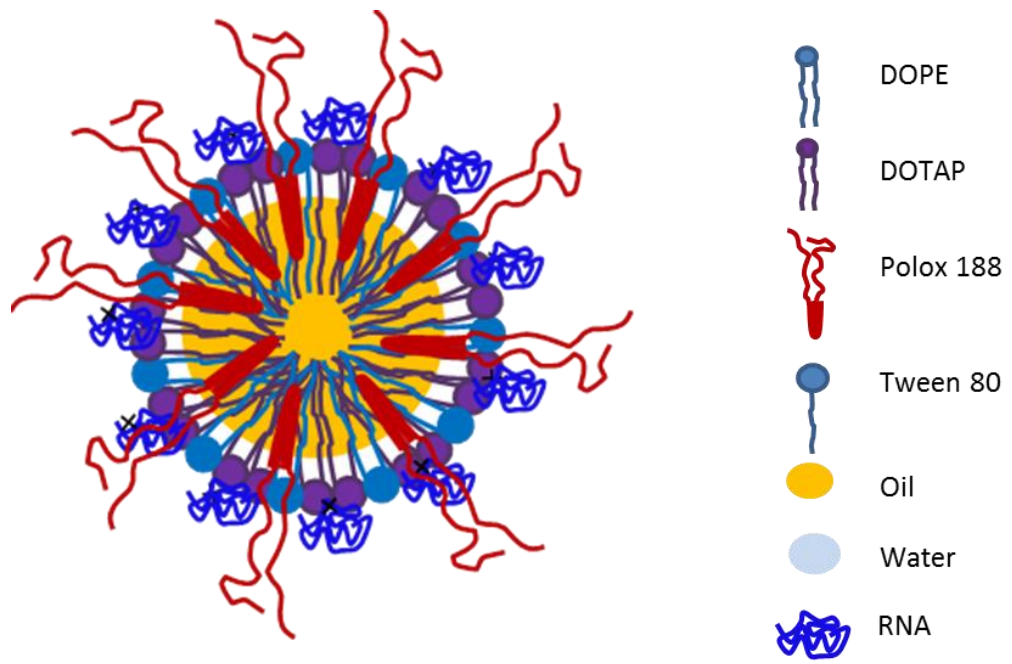

Fig. 2. Structure of cationic nanoemulsion/RNA complex. 


\section{METHODS}

\section{Cationic nanoemulsion (CNE) preparation}

As illustrated in Fig.3, the formulations shown in Table 1 were prepared as the following: in $15 \mathrm{ml}$ RNAses freefalcon tube, melt the oily phase (DOTAP, DOPE, Squalene) in hot water bath $\left(70{ }^{\circ} \mathrm{C}\right)$ until it is completely melted. Vortex to mix well until a homogenous paste is formed. Add the aqueous phase (Tween 80, poloxamer 188, water) priveously heated to $70{ }^{\circ} \mathrm{C}$ to the oily phase while both are hot. Vortex for complete mixing for 5 seconds. Then sonicate for $10 \mathrm{~min}$ (in ice bath) using probe sonicator UP 200S (HielscherUltrasonics, Teltow, Germany). The obtained nanoemulsion was kept at room temperature until needed.

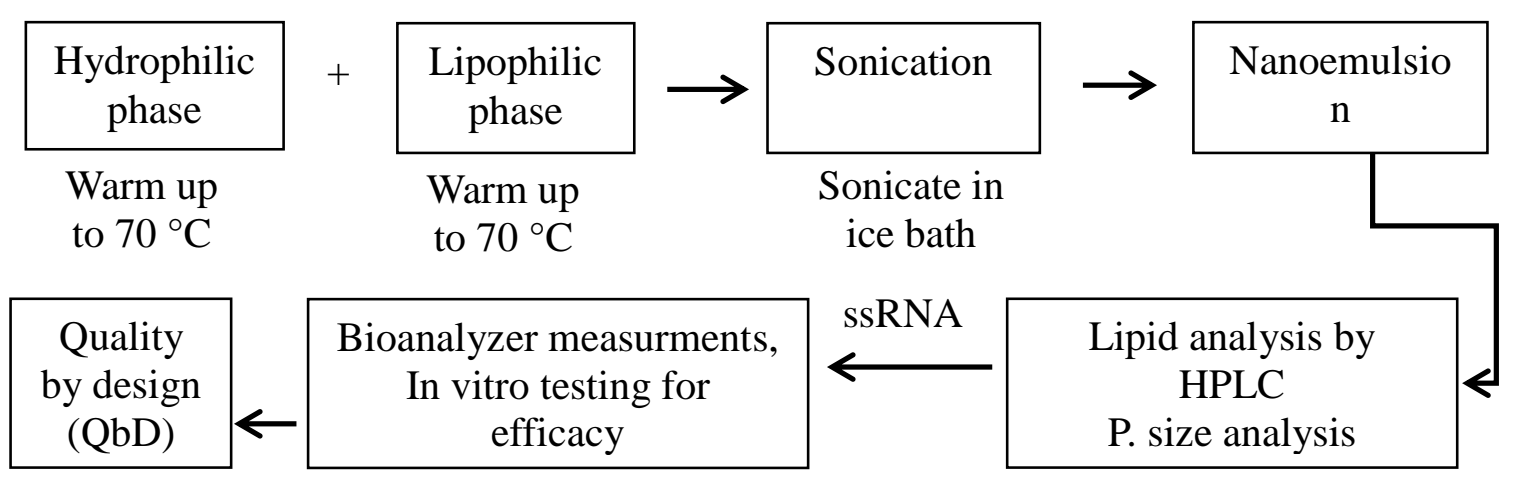

Fig. 3. Nanoemulsion preparation scheme.

Table (1): Experimental design layout

\begin{tabular}{|c|c|c|c|c|c|c|c|}
\hline Formulations & code & $\begin{array}{c}\text { Squalene } \\
{[\mathrm{mg} / \mathrm{ml}]}\end{array}$ & $\begin{array}{c}\text { Tween80 } \\
{[\mathrm{mg} / \mathrm{ml}]}\end{array}$ & $\begin{array}{c}\text { Polox 188 } \\
{[\mathrm{mg} / \mathrm{ml}]}\end{array}$ & $\begin{array}{c}\text { DOTAP } \\
{[\mathrm{mg} / \mathrm{ml}]}\end{array}$ & $\begin{array}{c}\text { DOPE } \\
{[\mathrm{mg} / \mathrm{ml}]}\end{array}$ & $\begin{array}{c}\text { Water } \\
{[\mathrm{g}]}\end{array}$ \\
\hline 1 & $-1 /-1$ & 10 & 0 & 0 & 1 & 1 & 0.988 \\
\hline 2 & $-1 / 0$ & 10 & 0 & 1 & 1 & 1 & 0.987 \\
\hline 3 & $-1 / 1$ & 10 & 0 & 10 & 1 & 1 & 0.978 \\
\hline 4 & $0 /-1$ & 10 & 1 & 0 & 1 & 1 & 0.987 \\
\hline 5 & $0 / 0$ & 10 & 1 & 1 & 1 & 1 & 0.986 \\
\hline 6 & $0 / 1$ & 10 & 1 & 10 & 1 & 1 & 0.977 \\
\hline 7 & $1 /-1$ & 10 & 10 & 0 & 1 & 1 & 0.978 \\
\hline 8 & $1 / 0$ & 10 & 10 & 1 & 1 & 1 & 0.977 \\
\hline 9 & $1 / 1$ & 10 & 10 & 10 & 1 & 1 & 0.968 \\
\hline
\end{tabular}

Factorial design:

Factors; X1: Tween 80 concentration $[\mathrm{mg} / \mathrm{ml}]$ and X2: Poloxamer 188 concentration $[\mathrm{mg} / \mathrm{ml}]$. 
Response: Y1: Particle size [nm], Y2: RNA binding [\%], Y3: INF a induction [formulation/standard \%].

\section{Determination of lipid recovery by HPLC}

Lipid recovery was quantified by HPLC. The HPLC system consisted of a G1311B quaternary pump, a G4212B DAD (diode array detector) detector, G1367E auto-sampler AS Hip, G1330B column oven thermostat, and ChemStation for LC revision B.04.02 (Agilent technologies, Colorado, USA). The stationary phase was Waters Sunfire C18 column (75 mm x $4.6 \mathrm{~mm} \times 2.5 \mu \mathrm{m}$ ) (Waters, Eschborn, Germany). The mobile phase was a mixture of methanol (70\%) and isopropanol (30\%). The flow rate and the column oven temperature were $2 \mathrm{~mL} / \mathrm{min}$ and $50^{\circ} \mathrm{C}$. The detection wavelength was $205 \mathrm{~nm}$. The injection volume amounted to $10 \mu 1$.

\section{Particle size, polydispersity index (PDI), and zeta-potential measurements}

Particle size, polydispersity index (PDI), and zeta-potential were routinely measured with a Nicomp 380ZLS laser light scattering particle sizer (Santa Barbara, California, USA). The optimum condition for measurements was applied.

\section{Formation of CNE/RNA complex}

According to the required ratio of cationic lipid/RNA (mole/base), the CNE added to an equal volume of RNA/H2O. The mixture incubated for at least 30 minutes to form CNE/RNA complex.

\section{Determination of bound RNA/total RNA in CNE/RNA complex}

One of the main factors influencing the efficacy of CNE/RNA complexs is the ratio of bound RNA/free RNA. Therefore, it is prerequisite to know how much of RNA is bound to $\mathrm{CNE}$ to form CNE/RNA complex. Hence, a new method was developed for quantification of bound/total RNA by using bioanalyzing technique. The Agilent's 2100 Bioanalyzer works as follows: Charged biomolecules like DNA or RNA are electrophoretically driven by a voltage gradient similar to slab gel electrophoresis. The molecules are separated by size. Smaller fragments are migrating faster than larger ones. Dye molecules intercalate into DNA or RNA strands or Protein-SDS micelles. These complexes are detected by laser-induced fluorescence. Data are translated into gel-like images (bands) and electropherograms (peaks). With the help of a molecular ladder that contains fragments of known sizes and 
concentrations, a standard curve of migration time versus fragments size is plotted. From the migration times measured for each fragment in the sample, the size is calculated. In our experiment, CNE/RNA complexs were prepared by mixing a calculated volume of CNE with RNA at a cationic lipid/RNA charge ratio of 2. CNE/RNA complexs were applied to the bioanalyzer chip and free RNA (unbound to lipid) was calculated from standard calibration curve of pure RNA measured in the same chip with the samples.

\section{In vitro assay (INF $\alpha$ induction)}

As shown in Fig. 4, human peripheral blood mononuclear cells (PBMCs) were isolated from Buffy Coat donations. After isolation, PBMCs $\left(5 \times 10^{5}\right.$ cells/well) were added to180 $\mu$ l of standard cell culture media (RPMI 1640, containing 10\% fetal calf serum (FCS), $2 \mathrm{mM}$ L-glutamine, $100 \mathrm{U} / \mathrm{mL}) .20 \mu \mathrm{l}$ of the formulation were mixed with the cells and incubated at $37{ }^{\circ} \mathrm{C}$ in presence of $5 \% \mathrm{CO} 2$ for $24 \mathrm{hr}$. CpGODN2216 and naked ssRNA, and cells only were used as a positive and negative control, respectively. Blood collected from two different donors were used. After 24 hours, INF $\alpha$ was quantified by using VeriKine ${ }^{\mathrm{TM}}$ Human Interferon Alpha ELISA Kit (PBL Assay Science, Piscataway, USA).(CpG ODNs which used as a positive control is a synthetic nuclease resistant oligonucleotide. CpG ODNs are recognized by Toll-like receptor 9 (TLR9) leading to strong immunostimulatory effects. They induce high IFN-a production from plasmacytoid dendritic cells (pDC).

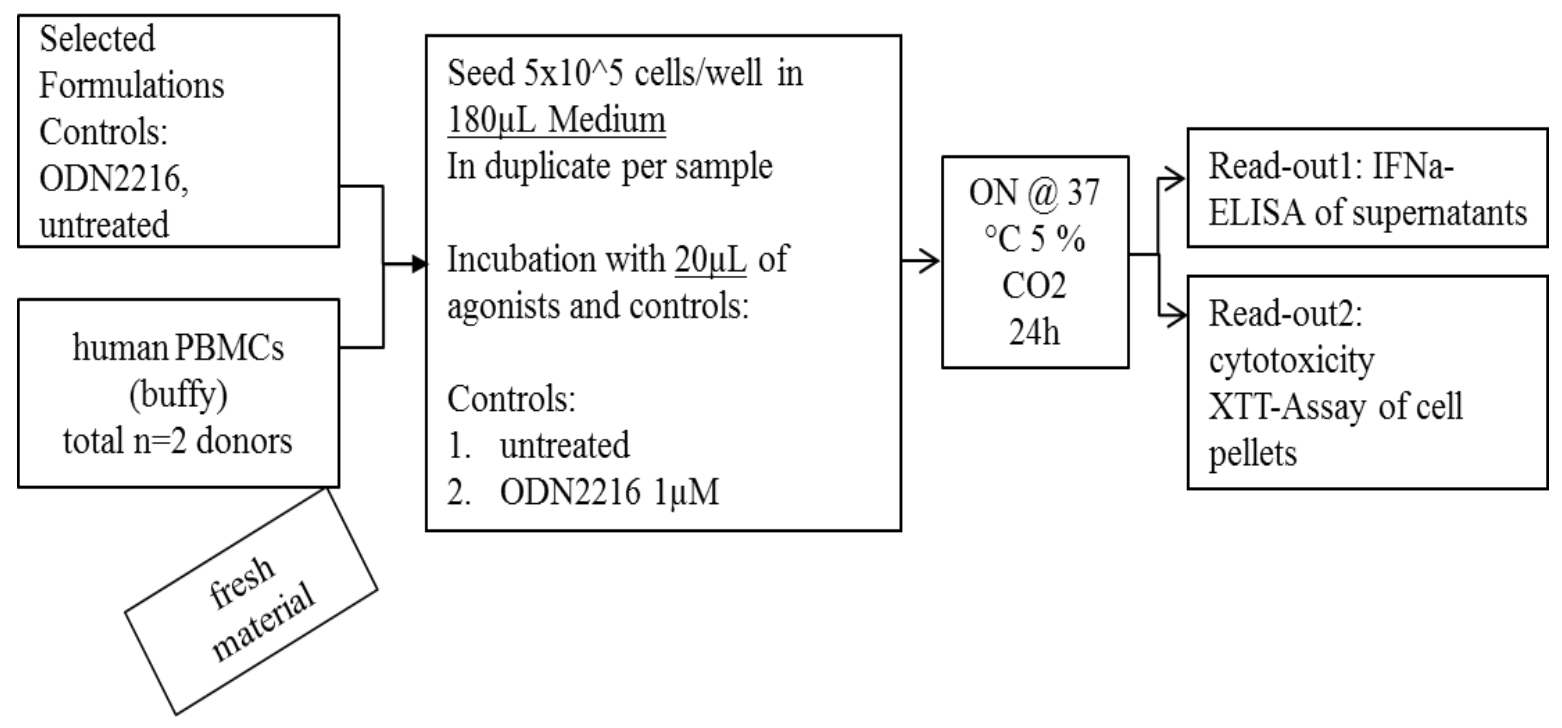

Figure 4: Scheme for in vitro assay. 


\section{RESULTS AND DISCUSSION}

\section{Quantification of lipid recovery by HPLC}

As shown in Table (2), all formulations showed a recovery \% between 97-115\% approximately.

Table (2). Lipid recovery by HPLC

\begin{tabular}{|l|l|l|l|l|}
\hline \multirow{2}{*}{ Formulation code } & \multicolumn{3}{|l|}{ Recovery [\%] } \\
\cline { 2 - 5 } & DOTAP & DOPE \\
\cline { 2 - 5 } & Mean & SD* & Mean & SD* \\
\hline 1 & 111.19 & 5.31 & 86,31 & 10.52 \\
\hline 2 & 120.37 & 4.27 & 112,35 & 5.32 \\
\hline 3 & 109.09 & 6.21 & 111,61 & 6.02 \\
\hline 4 & 118.18 & 2.11 & 103,42 & 4.21 \\
\hline 5 & 103.50 & 5.39 & 92,26 & 7.21 \\
\hline 6 & 120.68 & 4.51 & 98,96 & 2.27 \\
\hline 7 & 114.97 & 5.08 & 112,49 & 3.25 \\
\hline 8 & 116.84 & 2.54 & 113,84 & 5.57 \\
\hline 9 & 106.99 & 4.45 & 101,93 & 2.85 \\
\hline
\end{tabular}

$* \mathrm{SD}(\mathrm{n}=2)$.

\section{Particle sizes, polydispersity indices (PDIs), and zeta-potential of CNE}

As can be seen in Table 3 and Fig. 5, formulations with discrete particle sizes between 95 and $180 \mathrm{~nm}$ were obtained. Due to DOTAP lipid, zetapotential values were always positive. The narrow size distribution which is clear from the PDI values indicates the monodispersity of the particles. The influence of poloxamer 188 and tween 80 on particle size is clearly evident. Table 4 shows a very good correlation between $\mathrm{X} 1$ and $\mathrm{X} 2$ and $\mathrm{Y} 1\left(\mathrm{R}^{2}\right.$ $=0.995)$. One can see from Fig. 5 and 6 that by increasing the poloxamer 188 and/or tween 80, the particle size decreased. This is due to the decrease in the interfacial tension between the internal oil phase and continuous aqueous phase. On contrast for PDI values which show that by increasing the poloxamer 188 and/or tween 80 inside the set (formulations 1-3, 3-6, 
and 7-9), the PDI value increases. This means that the particles changed from monodisperse system to polydisperse system. This phenomenon could be explained that by increasing the surfactant and co-surfactants over limit, the molecules can't be inserted any more in the lipophilic membrane consequently form separate micellar systems which smaller in size in comparison to nanoemulsion particles. It is also clear from Fig. 6 that the influence of poloxamer $188(\mathrm{X} 2)$ is more predominant than tween $80(\mathrm{X} 1)$ regarding the particle size (Y1).

Table (3): Physicochemical characterization, RNA binding \%, INF $\alpha$ induction of CNE

\begin{tabular}{|c|c|c|c|c|c|c|c|}
\hline Formulation & code & $\begin{array}{l}\text { P.Size } \\
{[\mathrm{nm}]}\end{array}$ & PDIs & $\begin{array}{l}\text { Zeta } \\
\text { potential } \\
{[\mathrm{mV}]}\end{array}$ & $\begin{array}{l}\text { RNA } \\
\text { binding } \\
{[\%]}\end{array}$ & $\begin{array}{l}\text { Induction } \\
\text { of INF } \alpha \\
{[\mathrm{pc} / \mathrm{ml}]}\end{array}$ & $\begin{array}{l}\text { Induction of INFa } \\
\text { [Form./Control } \\
\%]\end{array}$ \\
\hline 1 & $-1 /-1$ & 180 & 0.12 & +49.83 & 100 & 120 & 20 \\
\hline 2 & $-1 / 0$ & 161 & 0.11 & +43.08 & 100 & 120 & 20 \\
\hline 3 & $-1 / 1$ & 94 & 0.20 & +39.16 & 100 & 480 & 80 \\
\hline 4 & $0 /-1$ & 172 & 0.13 & +41.95 & 100 & 540 & 90 \\
\hline 5 & $0 / 0$ & 145 & 0.18 & +40.16 & 100 & 240 & 40 \\
\hline 6 & $0 / 1$ & 121 & 0.29 & +38.14 & 100 & 300 & 50 \\
\hline 7 & $1 /-1$ & 145 & 0.21 & +37.72 & 95 & 360 & 60 \\
\hline 8 & $1 / 0$ & 150 & 0.24 & +21.13 & 88 & 60 & 10 \\
\hline 9 & $1 / 1$ & 125 & 0.37 & +39.46 & 10 & 60 & 10 \\
\hline ODN & - & - & - & - & - & 600 & 100 \\
\hline $\begin{array}{l}\text { Naked } \\
\text { ssRNA }\end{array}$ & - & - & - & - & - & 20 & 1.2 \\
\hline Cells only & - & - & - & - & - & 20 & 1.2 \\
\hline
\end{tabular}


Table (4). Actual, adjusted $\mathrm{R}^{2}$ and formulae for the three responses (Quadratic model)

\begin{tabular}{|l|l|l|l|}
\hline Item & Particle size[nm] & RNA binding [\%] & $\begin{array}{l}\text { INF } \alpha \text { induction } \\
{[\text { formulation /standard \%] }} \\
\text { Y3 }\end{array}$ \\
\hline Actual R & 0.9981 & Y2 & 0.9394 \\
\hline Adjusted R & 0.9949 & 0.9843 & 0.9383 \\
\hline Formula & & 100 & \\
Constant & 145 & -24 & 40 \\
X1 & -0.37 & -21 & -16.25 \\
X2 & -27.13 & -3 & 11.25 \\
X12 & -8.25 & -21 & -67.5 \\
X22 & -0.13 & -21 & 61.25 \\
X1X2 & 15.87 & -18.75 \\
\hline
\end{tabular}

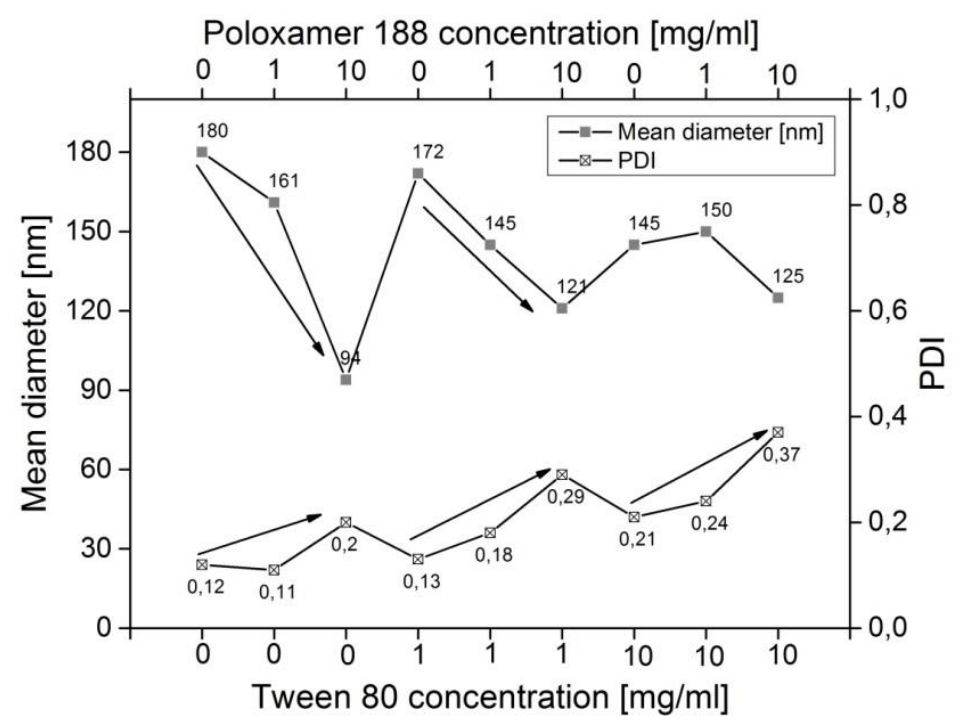

Fig. 5. Particle sizes, polydispersity indices (PDIs) of CNE formulations. 

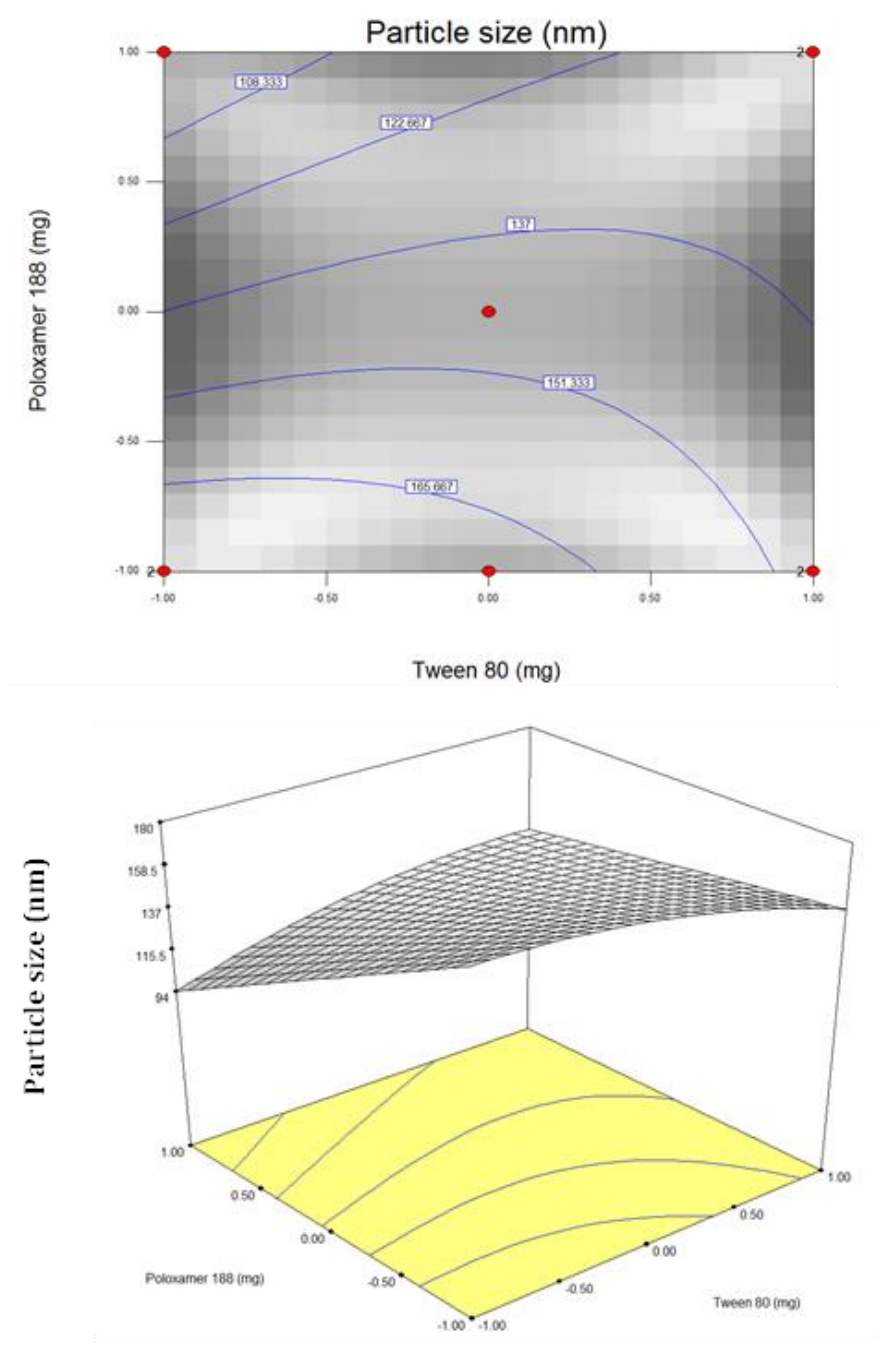

Fig. 6. Contour and 3D diagrams; effect of tween 80 (X1) and poloxamer 188 (X2) on particle size (Y1).

\section{Evaluation of RNA binding efficiency in CNE/RNA complex}

Comprising of positively charged lipid, DOTAP, in the formulations promote the adsorption of ssRNA on the particle surface as result of electrostatic interaction between the positive charge of DOTAP and negative charge of ssRNA. In all CNE/ssRNA complexs formulations, the molar ratio of the positive charge was 2-fold of the molar ratio of the negative charge $(+/-=2)$ to ensure the complete binding of ssRNA. After incubation of ssRNA with CNE for 30 minutes, the ssRNA binding efficiency was estimated. From table 3 and Fig 7 and 8, we see obviously that no free ssRNA in formulations 1-6 while formulations 7 and 8 showed about $10 \%$ of ssRNA are free. On contrast to formulation 9, $90 \%$ of ssRNA are free (the lowest binding efficiency). Table 4 shows a very good correlation between X1 and $\mathrm{X} 2$ and $\mathrm{Y} 2\left(\mathrm{R}^{2}=0.998\right)$. These results could be explained from the molecular conformation of the nanoemulsion particles in presence and absence of the poloxamer 188 and tween 80 . As we see from Fig. 2, the polyoxyethelene moiety of poloxamer 188 and 
polyethene glycol moiety of tween 80 configured on the surface of the particle since they are the hydrophilic moieties of both molecules. By increasing the concentration of both, their hydrophilic moieties cover completely the particle surface forming hydrophilic shell. This shell results in shielding of the positive charge of DOTAP consequently inhibit the electrostatic interaction with the negative charge of ssRNA as we see clearly in formula 9.

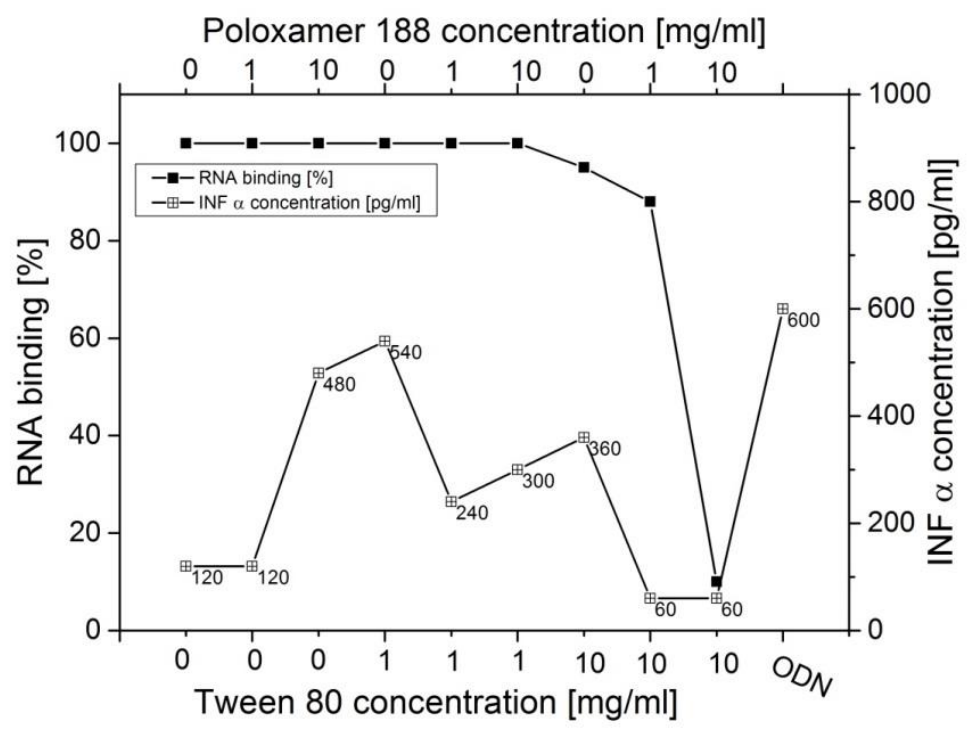

Fig. 7.Determination of bound RNA/total RNA in CNE/RNA complex. 

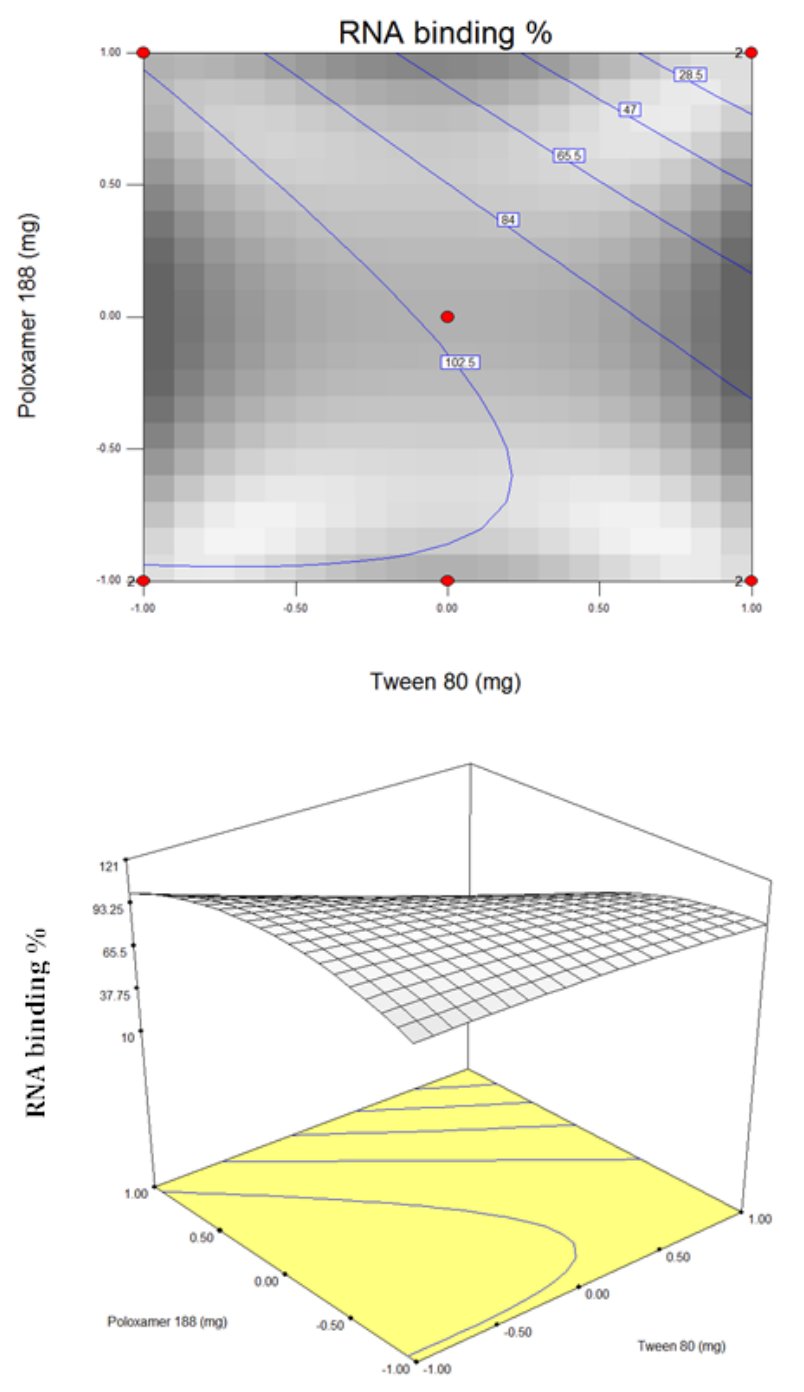

Fig. 8. Contour and 3D diagrams; effect of tween $80\left(\mathrm{X}_{1}\right)$ and poloxamer $188\left(\mathrm{X}_{2}\right)$ on RNA binding $\%\left(\mathrm{Y}_{2}\right)$.

\section{INF $\alpha$ induction}

After incubation of all formulation with human PBMCs for 24 hours, INF awas quantified and compared to INF $\alpha$ induced by CpG ODNs which induce high INF $\alpha$ production from plasmacytoid dendritic cells (pDC) therefore used as a positive control. Free ssRNA does not show INF a production due to degradation by nucleases. Table 4 shows a good correlation between $\mathrm{X} 1$ and $\mathrm{X} 2$ and $\mathrm{Y} 3\left(\mathrm{R}^{2}=0.93\right)$ which mean that poloxamer 188 and/or tween 80 influencing significantly the INF $\alpha$ production. As shown in Table 3 and Fig. 9 and 10, although most of the formulations showed a high binding efficiency of ssRNA, the formulations 3 and 4 induced the highest amount of INF $\alpha$.Interestingly that in both 
formulations either poloxamer 188 is present (F3) or tween 80 is present (F4) but where both together in one formulation, the INF $\alpha$ production decreased relatively. While it is evident that the transfection activity was increased by incorporating PEG moiety (tween 80) or polyoxyethylene moity (poloxamere 188), the mechanism is not exactly known at present. However, the enhancement of transfection activity by the PEG or polyoxyethylene moity seemed to be affected mainly by the stabilization of the complex. It is highly probable that PEG or polyoxyethylene moity increases the emulsion stability. They are good emulsifiers and form more stable emulsions; the emulsion stability may be related closely to transfection activity (Yi et al., 2000; Kim et al., 2001). There is, however, another hypothesis that PEG or polyoxyethylenemoitymay have a similar fusogenic property to DOPE (Liu et al., 1996). Generally, non-ionic surfactants are known to destabilize the cell membrane since the lipid can extract the protein from the membrane to increase the membrane fluidity (Liu et al., 1996). There is a report that the PEG-lipid-modified liposome directly fused with the plasma membrane of a Jurkat cell (Higashi et al., 1996).

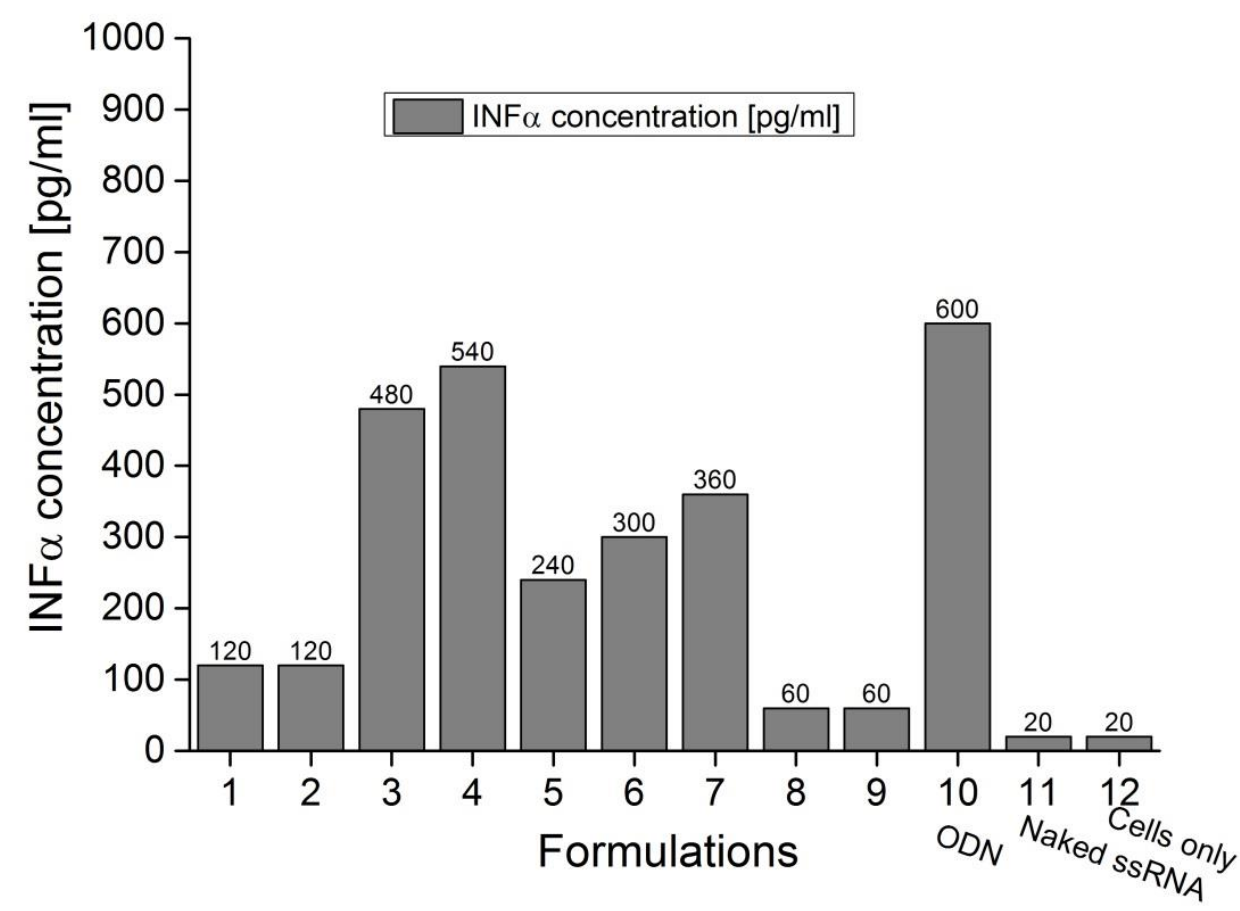

Fig. 9. INF $\alpha$ induction profile of all tested formulations and controls. 


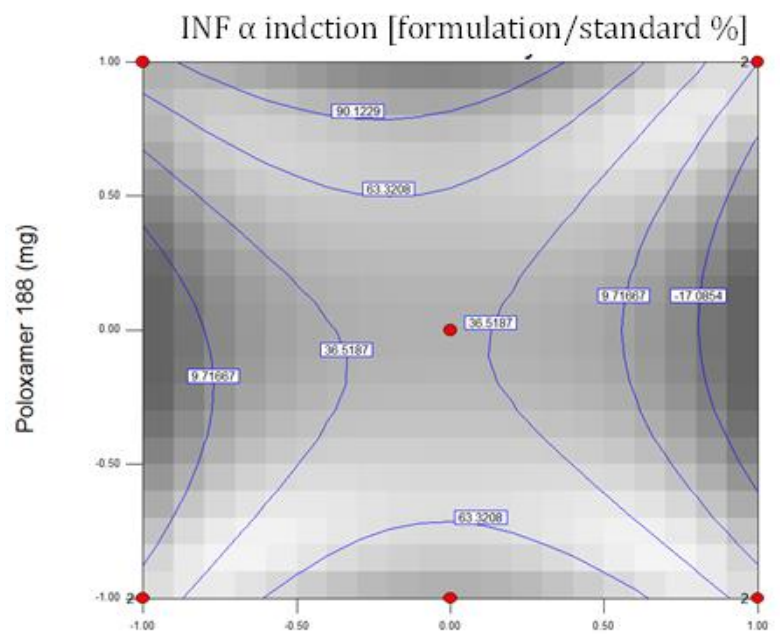

Tween $80(\mathrm{mg})$

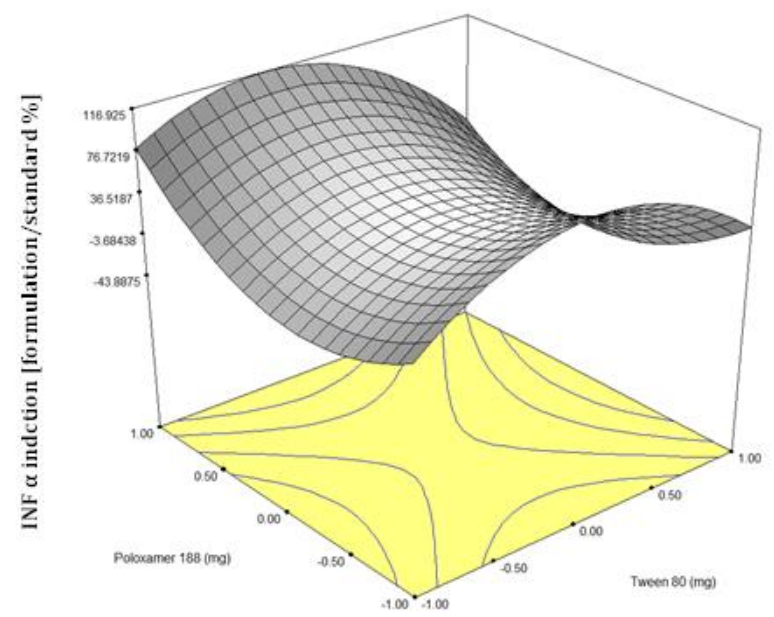

Fig. 10. Contour and 3D diagrams; effect of tween $80\left(\mathrm{X}_{1}\right)$ and poloxamer $188\left(\mathrm{X}_{2}\right)$ on INF $\alpha$ induction $\left(\mathrm{Y}_{3}\right)$.

\section{CONCLUSION}

Cationic nanoemulsion could be a promising drug delivery system for nucleic acids (DNA/RNA) in cancer and viral immunotherapy. Formulations with discrete particle sizes and narrow size distribution could be prepared. Poloxamer 188 and tween 80 concentrations decrease significantly the particle size. Functionality of the CNE diminished if the RNA adsorption to particles surface was inhibited. It is also obvious that poloxamer $188 \mathrm{and} /$ or tween 80 influencing significantly the INF $\alpha$ production. The transfection activity was increased by incorporating PEG moiety (tween 80 ) or polyoxyethylene moity (poloxamer 188). 


\section{Future work}

Application of CNE/RNA complex in tumor bearing mice to investigate functionality in vivo.

\section{Acknowledgment}

I'm so grateful to prof. Dr. Ibrahim Khatab, professor of pharmaceutics and industrial pharmacy, for supporting quality by design part.

I would like to thank also Dr. Sherif Khalifa, lecturer of pharmaceutics and industrial pharmacy, Faculty of Pharmacy, Al-Azhar University, Cairo, Egypt, for his support and scientific advices.

\section{REFERENCES}

Akira S., Uematsu S., Takeuchi O., (2006): Pathogen recognition and innate immunity. Cell, 124(4): 783-801.

Brigger I., Dubernet C., Couvreur P., (2002): Nanoparticles in cancer therapy and diagnosis. Adv Drug Deliv Rev;54:631-51.

Briones M., Singh M., Ugozolli M., Kazzaz J., Klakamp S., Ott G., O'Hagan D. T., (2001): The preparation, characterization and evaluation of cationic microparticles for DNA vaccine delivery, Pharm. Res., 18, 709-712.

Diebold S. S., Kaisho T., Hemmi H., Akira S., Reis E., Sousa C., (2004): Innate antiviral responses by means of TLR7-mediated recognition of single-stranded RNA. Science; 303(5663):1529-1531.

Heil F., Hemmi H., HochreinH., (2004):Species-specific recognition of single-stranded RNA via Toll like receptor 7 and 8. Science.; 303(5663):1526-1529.

Hemmi H., Kaisho T., Takeuchi O., (2002):Small anti-viral compounds activate immune cells via the TLR7 MyD88-dependent signaling pathway. Nat. Immunol. (2):196200.

Hemmi H., Takeuchi O., Kawai T., (2000):A Toll-like receptor recognizes bacterial DNA. Nature; 408(6813):740-745. 
Higashi N.,Yamauchi M., Okumura Y., Nakanishi M., Sunamoto J., (1996): Fusion between Jurkat cell and PEO-lipid modified liposome, Biochim. Biophys.Acta,1285 (2) 183-191.

Hong K., Zheng W., Baker A., Papahadjopoulos D., (1997): FEBS Lett. 400, 233-237.

Ito T., Amakawa R., Kaisho T., Hemmi H., Tajima K., Uehira K., Ozaki Y., Tomizawa H., Akira S., Fukuhara S., (2002): Interferon-alpha and interleukin-12 are induced differentially by Toll-like receptor 7 ligands in human blood dendritic cell subsets. J Exp Med 195: 1507-1512

Jorge L. C., Bennett W., Chaitali B., JuanC. S., (2012): TLR8: the forgotten relative revindicated.Cellular\&MolecularImmunology,9, 434-438.

Kawai T. and Akira S., (2010): The role of pattern-recognition receptors in innate immunity: update on Toll-like receptors. Nat. Immunol. 11(5):373-384.

Kim T.W., Chung H., Kwon I.C., Sung H.C., Jeong S.Y., (2001):Optimization of lipid composition in cationic emulsion as in vitro and in vivo transfection agents, Pharm. Res. 18, 54-60.

Krieg A.M., (2008): Toll-like receptor 9 (TLR9) agonists in the treatment of cancer. Oncogene; 27(2): 161-167.

Liu F.,Yang J., Huang L., Liu D., (1996): Effect of non-ionic surfactants on the formation of DNA-emulsion complexes and emulsion-mediated gene transfer, Pharm. Res. 13, $1642-1646$.

Lund J.M., Alexopoulou L., Sato A., (2004): Recognition of single-stranded RNA viruses by Toll-like receptor 7. Proc. Natl Acad. Sci. USA.; 101(15):5598-5603.

SchonM.P.andSchon M., (2008): TLR7 and TLR8 as targets in cancer therapy. Oncogene; 27(2):190-199.

Smits E.L., Ponsaerts P., Berneman Z.N., Van Tendeloo V.F., (2008): The use of TLR7 and TLR8 ligands for the enhancement of cancer immunotherapy. Oncologist, 13(8):859-875. 
Tae W. K., Young J. K., Hesson C. I., Chan K., Ha C. S., Seo Y. J., (2002): The role of non-ionic surfactants on cationic lipid mediated gene transfer, J. Control. Release;82 $455-465$

Teixeira H., Dubernet C., Puisieux F., Benita S., Couvreur P., (1999): Submicron cationic emulsions as a new delivery system of oligonucleotides, Pharm. Res. 16, 30-36.

Teixeira H., Dubernet C.,Rosilio V., Laigle A., DeverreJ.R.,Scherman D., Benita S. S., Couvreur P., (2001): Factors influencing the oligos release from o-w submicron cationic emulsions, J. Control. Release 70, 243-255.

ThierryA.R., Rabinovich P., Peng B., Mahan L.C, BryantJ.L., GalloR.C., (1997): Charcterization of liposome-mediated gene delivery: expression, stability and phramacokinetics of plasmid DNA, Gene Ther, 4, 226-237.

YiS.W., Yune T.Y., Kim T.W., Chung H., Choi Y.W., Kwon I.C., Lee E.B.,. Jeong S.W, (2000): A cationic lipid emulsion/ DNA complex as a physically stable and serumresistant gene delivery system, Pharm. Res., 17, 314-320.

Zabner J., (1997): Cationic lipids used in gene transfer, Adv. Drug Del. Rev. 27,17-28.

Zelphati O., Uyechi L. S., Barron L.G., Szoka F.C, (1998):Biochim. Biophys.Acta, 1390, 119-133) 


\title{
استخدام مستحلب نانوميترى ذو شحنة موجبة كصيغة دو ائية لنقل الروابط المستخدمة فى علاج

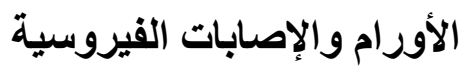

\author{
للسيد الدكتور \\ حسام حفيشّا

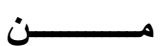 \\ المدرس بقسم الصبدلانيات و الصيدلة الصناعيةـ كلية الصيدلةـ بنين- جامعة الأزهر ـ القاهرة \\ جمهورية مصر العربية
}

ان تنشيط مستقبلات ت ل ر ببعض الروابط الطبيعية او الصناعية يؤدى الى تنشيط الجهاز المناعى و من ثم

يفرز بعض السيتوكينات و يزيد من خاصية التهام الأجسام الغريبة و تحلاها بواسطة الخلايا ذات الطبيعة الدفاعية. و من هنا فان الهدف من هذا البحث هو تحضير مستحلب نانوميترى ذو شحنة موجبة، عالى الثباتية، فعال و غير سام حتى يتم استخدامه كناقل لأحد الروابط الطبيعية ذات الثحنة السالبة. وقد تم أولا تحضير المستحلب من زيت الاسكو الين و دهن

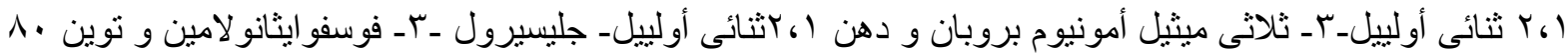

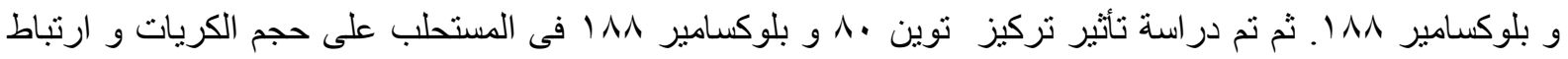
الر ابط بالمستحلب و اخير أ فاعلية الرابط حين ارتباطه بالمستحلب.

هذا وقد أظهرت النتائج ان كلا من توين • ^ و بلوكسامير 11 ا يؤثر على حجم كريات المستحلب و كذلك ارتباط

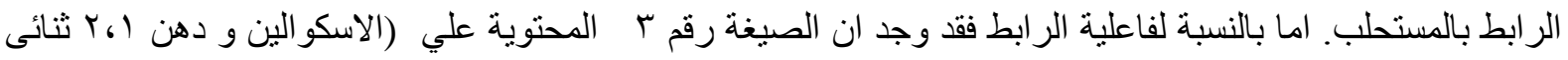

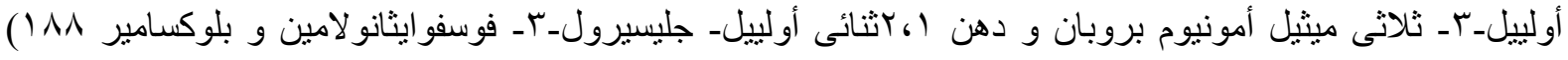

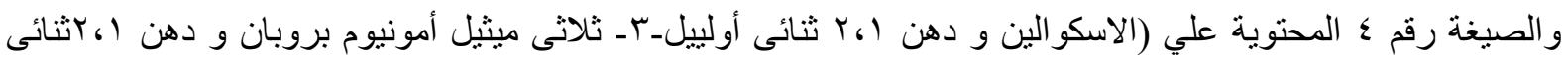
أولييل-جليسيرول_r - فوسفو ايثانو لامين و توين • ^) ذوات فاعلية عالية توحى بامكانية استخدامه فى الحيو انات التجريبية.

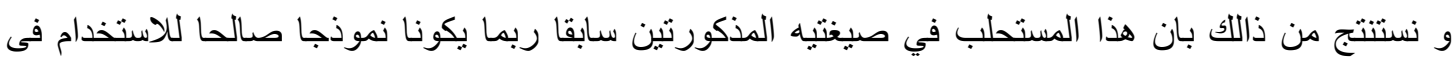

علاج الأورام و الإصابات الفيروسية عن طريق تتشيط الجهاز المناعى. 